\title{
French Agricultural Policies and the Transformation of Social Structure in a Village \\ -A Case Study of Brux-
}

Tatsuro Suehara (Graduate School of Agriculture, Kyoto University)

\section{Introduction}

The number of family farmers in France one of the major agricultural producers in Europe - declined quite drastically in 1990's. Compared with the beginning of 1980's, the end of 1990's saw the social structure of many rural communities transformed. In 1999 the New Agricultural Basic Law designed to deal with these changes (and which includes new policies such as C.T.E. or Territorial Contract of Farm Management) was introduced. The purpose of this study is to analyze how the social structure of France's rural community was transformed in the 1980's and 1990's and to clarify to what degree this transformation is affected by French agricultural policies which are based on the Common Agricultural Policies (C.A.P.) of the European Union.

\section{The Study of Transformation of Social Structure in French Rural Communities}

After World WarII, the French rural populations - which has hitherto to been engaged in agriculture only - began to take on other kinds of work. In 1960's, some French rural sociologists such as Gervais, Servolin et Weil, Une France sans paysans ${ }^{1)}$, and Mendras, La fin des paysans ${ }^{2)}$, wrote of the crisis affecting the rural populations of the countryside. Looking at population statistics which showed a reduction in the peasant from $3,980,000$ in 1954 to just $3,010,000$ in 1962 (or from $26.8 \%$ to $20.0 \%$ of the working population), they argued that France's peasant farmers were in terminal decline. Their arguments proved premature, in spite of future declines in the 1970's. The author's research shows that the real disappearance of the French peasantry began in the 1990 's, when the agricultural workers population finally fellow 5 per cent. (Table 1)

Most Japanese studies of French agriculture $^{3)}$ are focused on goverment policies, especially the New Agricultural Basic Laws and Common Agricultural Policies. Only Korenaga ${ }^{4)}$ has conducted a long-term structural analysis of French agriculture. There are few community studies based on the rural sociology.

One important study in France is a comparative study of rural area in France and in England conducted by Maryvonne Bodiguel and Philip Lowe in the 1980's with the results published in $1989^{5}$ ).

Robert Layton also wrote an ethnological and historical monograph of the FrenchComté after thirty years of intermittent research ${ }^{6)}$. In the recent new wave of rural studies, villagers have described their own soci-

Table 1 Development of Farmers in France

\begin{tabular}{crrrrrrr}
\hline & \multicolumn{1}{c}{1954} & \multicolumn{1}{c}{1962} & \multicolumn{1}{c}{1968} & 1975 & 1982 & 1990 & 1997 \\
\hline Farmers ('000) & 3984 & 3011 & 2460 & 1652 & 1448 & 982 & 680 \\
Farm Workers ('000) & 1151 & 830 & 588 & 372 & 304 & 282 & 277 \\
Total Agricultural Workers ('000) & 5135 & 3841 & 3048 & 2024 & 1752 & 1264 & 957 \\
Total Working Population ('000) & 19151 & 19164 & 20439 & 21771 & 23525 & 25033 & 25582 \\
Percentage of Agricultural Workers (\%) & 26.8 & 20 & 14.9 & 9.3 & 7.5 & 5 & 3.7 \\
\hline
\end{tabular}

Sources: INSEE, L'agriculture, la forêt et les industries agroalimantaires 1999, Agreste, 1999, INSEE, Contours et caractere: les agriculteurs - Portrait social, 1993. 
ety and life in books such as Paroles et Parcours de Paysans: Nous avons cru au progress written by G.R.R.S. (Groupe de Recherches Ethnologiques de l'Anjou's) in 19967). This new approach to the study of French rural communities-based on the paroles of the villagers themselves verified the strong influence of agricultural policies on the recent social transformation of French rural communities.

\section{Method and Study Area}

The research village Brux is located in the central eastern part of the Région PoitouCharentes in southwestern France. Agriculture of Poitou-Charentes is classified as système mixte polyculture (mixed farming system), which is different from grandes cultures (major crops cultivation) in Illes de France and élevage dominant (livestock rearing dominated farming) in Massif Central and Massif Armoricain. In the Région de Poitou-Charents there are 1,465 communities (communes). Brux is one of these communities all of which are classified by INSEE into seven types as follow: (1) urban community in central urban area, (2) urban community in peripheral urban area, (3)urban community in inter urban area, (4) rural community under urban area, (5)central rural community, (6) rural community in peripheral area and (7) isolated rural community. Brux is classified as an isolated rural community.

Brux, which had 687 inhabitants in 1999 , is a community that covers 5,591 ha of land including 2,353 ha of farmland. The official numbers of farmers is calculated at 30 , but only 20 of these are farmers who work on his or her

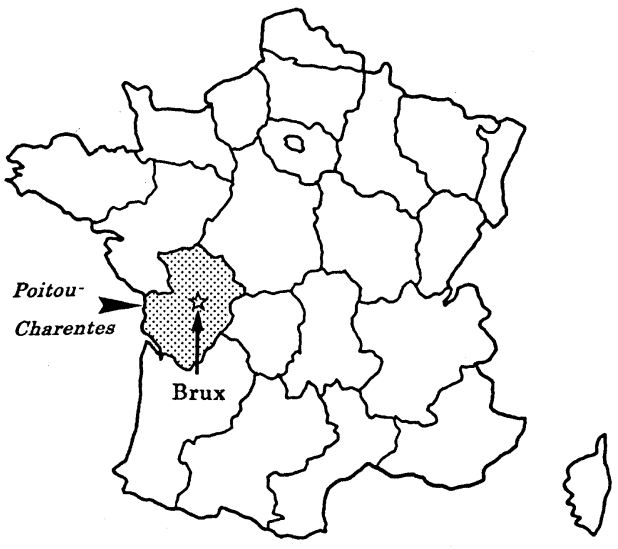

Fig. 1 Study Area

farm as a principal activity. (Table 2)

The author interviewed 12 of these professional farmers as well as other villagers such as a village chief, some farm retirees, newly arrived farmers, a cultural adviser to the community and some spouses of these individuals. The author also interviewed some village outsiders on the subject of village agriculture and social life. These included administrative officers in the region; a member of the French Parliament; agricultural business entrepreneurs in the surrounding communities; owners of a farmer's restaurant; clerks dealing with the financing of the Agricultural Bank and technocrats from the French Ministry of Agriculture and Fisheries. These interviews and collection of data were conducted in July and August in 1999 and 2000.

\section{Transformation of Agrarian and Social Structure in Brux \\ The number of farmers declined from 93 in}

Table 2 Development of Farmers and Agricultural Workers in Brux

\begin{tabular}{crrrr}
\hline & 1970 & 1978 & 1988 & 2000 \\
\hline Farmers & 134 & 93 & 68 & 30 \\
Professional Farmers & $\mathrm{n}$. & 58 & 45 & 20 \\
Utilized Agricultural Area (ha) & 2115 & 2137 & 2282 & 1731 \\
Population of Farmer's Family & 480 & 324 & 215 & $\mathrm{n}$. \\
Agricultural Workers & 288 & 185 & 146 & 49 \\
\hline
\end{tabular}

Sources: Fiche Profil-Commune Brux, Recensement agricole 2000, centre de documentation et d'information. 
1978 to 30 in 2000 . The number of professional farmers also declined from 58 in 1978 to 20 in 2000. Why and how did two thirds of the farmers in Brux stop farming during these two decades? In the interviews, it is clear that most of them preferred to retire from agriculture using the new pré-retraite (early retirement) system. Under this system for example, a dairy production farmer who is over 55 years old and resigned from dairy production has for five years the right to be subsidized by 2.5 francs every liter of cow's milk which he produced.

Because of this subsidy, many farmers become retirees living on pension and receiving ground rent. As a result, the majority of villagers are now retirees, not farmers. Indeed these days, it is difficult to find active farmers over sixty years of age in Brux, whereas men of the same age are still a central force of Japan's agricultural production.

The reduction in the number of active farmers has actually led to an increase in the average size of Brux farm. 91 per cent of Brux farmers had less than 50 ha in 1979, but in 2000 only 53 per cent of farms were of this size. Meanwhile the average farm size over 50 ha has increased from 73 ha to 99 ha.

As an example, three of the twelve farmers interviewed manage farms of 190 ha, 154 ha and 125 ha of respectively, but when they began farming they had 3-23 ha of their own land. The increase in size is due to their subsequent purchase or renting of additional landmost of it from retirees. Over the past twenty years some small or middle size farmers have moved from mixed farming to large-scale cereal crop cultivation. Their main crops are wheat, maize, rape and sunflower, the last three of them are not the traditional plants in Brux. Indeed Fields of sunflowers have changed the landscape of the village radically. Their reason for growing these crops is again related to the direct payment of government subsidies to farmers who plant oleaginous seeds.

The development of distribution of area of cereal crops and oleaginous crops in Brux is shown in Table 3. (Table 3)

The area of wheat in the end of 1970's is 671 ha, which is 31 per cent of the U.A.A. (Utilized Agricultural Area). This declines to 479 ha in 2000. On the other hand the area given over maize in 1979 is 261 ha and this increases to 400 ha in 2000. A similar increase is found in the area devoted to rape and sunflower, -11 ha to 126 ha, and 54 ha to 398 ha respectively.

\section{Conclusion}

It is clear that agrarian and social structure in Brux has been transformed over the past two decades. The transformation of the agrarian structure of Brux can be summarized as follows:

1) The number of family farmers declined drastically in 1980's to 1990's. (French agricultural policies led many farmers to take early retirement.)

2) The average area of farm size roughly doubled.

Table 3 development of Cereal and Oleaginous Production in Brux

\begin{tabular}{crrrr}
\hline & 1970 & 1979 & 1988 & 2000 \\
\hline Farmers & 134 & 93 & 68 & 30 \\
Utilized Agricultural Are (ha) & 2115 & 2137 & 2282 & 1731 \\
Wheat (ha) & 433 & 671 & 689 & 479 \\
Barley (ha) & 462 & 343 & 102 & 67 \\
Maize (ha) & 154 & 261 & 363 & 400 \\
Rape (ha) & 38 & 11 & 91 & 126 \\
Sunflower (ha) & 0 & 54 & 469 & 398 \\
\hline
\end{tabular}

Sources: Fiche Profil-Commune Brux, Recensement agricole 2000, centre de documentation et d'information. 
3) Most family farms changed into large scale agricultural enterprises (E.R.R.L.: Exploitation Agricole à Resposabilité Limiteé) or agricultural community group (GAEC: groupement agricole d'exploitation en commun).

4) Traditional crops in Brux were replaced by maize and new oleaginous crops such as rape and sunflower.

5) Traditional mixed farming farmers divided into three main groups: large cereal farmers, large dairy farmers and small mixed farming farmers.

6) In the 1990's new type of farmer's work such as farmer's restaurant and gites (farmer's bed and breakfast) have begun and attract a significant number of urban people.

7) Some small farmers have begun to consider applications for C.T.E., but no one has done so yet.

It is cleared that first five areas of change listed above have been shaped by recent government agricultural policies, but the New Agricultural Basic Law have not yet had much effect.

There is no doubt that the social structure of Brux was transformed by the government's agricultural structural transformation plans. The author point out six characteristics of this transformation, as follows:

1) Most of the inhabitants of the village are retirees.

2) Agriculture is no longer the central concern of village life.

3) Specialized farmer or farm manager cannot be seen as peasants in any traditional sense but as manager of an agricultural enterprise.

4) The irrigated farming system based on pumped up underground water has changed the image of French farming from being one that in harmony with the environment to one that is considered a factor in environmental destruction.

5) Village life has lost much of its energy and direction and there is a tendency for villagers to stay indoors much of the day since they have no pressing economic concerns.

6) The most important goal or focus of the village today is to animate and motivate the community through cultural and social promotions based on the community's traditional identity and history. These include donkey festivals or shows in which old "classic" tractors are displayed. Some towns have even set up agricultural museums for tourists with displays of old equipment or various types of scarecrow.

\section{Notes}

1) Gervais, Servolin et Weil, Une France sans paysans, le Seuil, 1965

2) Henri Mendras, La fin des paysans, Paris, Sedeis Futuribles, 1967

3) Toshinobu Kitabayashi, New Agricultural Basic Law of France-Its Substance and the Necessity of Enactment, p.6-p.33, Study on Agricultural Structure, no.204, 2000.

Keiich Ishii, Outline of CTE (Territorial Contract of Farm Management) System and its Importance, p.53-p.88, Study on Agricultural Structure, no.204, 2000

4) Tohiko Korenaga, Mountain Agriculture in France, Nousan-gyoson bunka kyokai, 1998, A Short History and Characteristics of Agrarian Structure in France, Nihon keizai hyoron-sha, 1993, Comparative Studies of France's and Japan's Agricultural Basic Laws, p.106-p.151, Study on Agricultural Structure, no.204, 2000.

5) Maryvonne Bodiguel et Philip Lowe, Campagne Française, Compagne Britannique, L'Harmattan, 1989

6) Robert Layton, Anthropology and History in Franche-Comté: A Critique of Social Theory, Oxford University Press., 2000

7) Groupe de Recherches Ethnologiques de l'Anjou, Paroles et parcours de paysans: Nous avons cru au progrés, L'Harmattan, 1996 


\section{References}

[1] INSEE, Quelques chiffres sur le PoitouCharentes en 2000, INSEE, 2000

[2] Service régional de statistique agricole région Poitou-Charentes, Annuaire 1999 région Poitou-Charentes, direction régionale de agriculture et de la forêt, 1998

[3] G.Labrune, La géograhie de la France, Editions Nathan, 1998

[4] INSEE, Inventaire communal de 1998, INSEE, 1998

[5] région Poitou-Charentes S.R.S.A., D.R.A.F., Annuaire 1999, service régional de statistique agricole région PoitouCharentes, 1999

[6] Labrune, La géographie de la France, Editions Nathan, 1994, p.87

[7] Ministère de l'agriculture et de la pêche, l'agriculture, la forêt et les industries agroalimantaires 1999

[8] Gervais, Servolin et Weil, Une France sans paysans, le Seuil, 1965
[9] INSEE, Contours et caractére: Les agriculteurs - portrait social, INSEE, 1993

[10] INSEE, L'agriculture, la forêt et les industries agroalimantaires 1999, Agreste, 1999

[11] Henri Mendras, La fin des paysans suivi d'une réflexion sur la fin des paysans vingt ans après, Actes Sud, 1984

[12] Monographies des villes et villages de France, Couhé et ses environs, 1989

[13] INSEE Poitou-Charentes, Poitou-Charentes - Démographie 1821-1992, 1993

\section{Acknowledgements}

I am very grateful to Centre de documentation et d'information Agreste, Ministère de l'agriculture et de la pêshe. This field research was supported by a grant of Monbusho (Ministry of Education and Culture of Japan) International Scientific Research Program entitled 'Comparative Study of Agriculture, Environment and Durableness of Local Communities' (No.1069076) 